\title{
A política de proteção e elevação das raças exóticas do Brasil nos Séculos XVI a XVIII*.
}

\author{
Waldemar Ferreira \\ Professor Emérito da Faculdade de Direito da \\ Universidade de São Paulo.
}

$\S 10^{\circ}$

Sumário: 1. A raça encontrada pelos descobridores na Terra de Vera Cruz. 2. A carta de PeRo VAZ DE CAMinha. 3. O apêlo do cronista a El-rei em prol do gentio. 4. $O$ abandono da terra recém descoberta. 5 . O povoamento da costa do Brasil pelo regime das capitanias de juro $e$ herdade. 6. A categoria da populậão da nova colônia lusitana. 7. A contingência e formas da escravização da raça indígena.

\section{$\S 2.0^{\circ}$}

8. O regimento do primeiro Governador Geral do Brasil. 9. A ruptura da paz reinante entre os colonos e o gentio. 10. A política de conversão dos índios à fé cristã. 11. $O$ protesto dos jesuitas contra a escravização indígena pelo resgate. 12. Os africanos nos primeiros tempos da colônia. 13. A atuação da raça européia sôbre a indígena nos três primeiros séculos da colônia.

$\S 3 .^{\circ}$

14. As dificuldades do cumprimento da libertação dos indios pela lei de 1696. 15. As provisões ditadas em 1605.

*. Relatório do Tema b) da IIr. ${ }^{a}$ Secção - A Organização Social $e$ o Direito, do Temário do v.o Colóquio Internacional de Estudos Luso-Brasileiros, celebrado de 2 a 8 de setembro de 1963, em Coimbra. 
16. A atuação do PADRe ANTônio Vieira na emergência. 17. A carência de sentido agricola na exploração $d a$ indústria açucareira. 18. A decifração do enigma do sertão pelo bandeirismo paulista. 19. A divisão dia colônia em dois Estados autônomos - o do Brasil e o do Maranhão. 20. O plano colonizador do Pará e Maranhão pelo PAdRE ANtônio Vieira. 21. A punição dos senhores no castigo excessivo de seus escravos.

\section{$\S 4 .^{\circ}$}

22. A diminuição da população gentia da costa do Brasil, por efeito da escravidão. 23. $O$ direito de cidadania dos indios casados com vassalos. 24. A elevação do índio no conceito público. 25. A lei de libertação dos escravos. 26. O Regimento do Diretório. 27. A subsistência da escravidão dos negros.

\section{$\S 10^{\circ}$}

1. Quando, na última semana de abril de 1500, a armada de Pedro Álvares Cabral, partida do Tejo nos primeiros dias do mês anterior com destino à Índia, desviando-se da rota seguida pela de VASco Da Gama, tendo terra à vista, no dia 21 de abril, procurou pôrto seguro em que as caravelas lançassem âncoras e, encontrando-o, nele vieram a desembarcar, os navegantes se acharam tomados de surprêsa e mesmo atônitos. Que terra seria aquela? A da Índia? Num batel, que avançou para terra, seguiu Nicolau Coelho, que já andara pela Índia. Fêz indagações, que não puderam ser satisfeitas, pelo desentendimento de língua; e a gente, que a habitava, era de "homens pardos, nus sem nenhuma coisa que lhes cobrisse suas vergonhas", como escreveu o cronista da armada. Também não eram negros, como asseverou Bartolomeu Dias.

Nessa situação, deu o comandante da frota à terra o nome de Terra da Vera Cruz; mas a seus habitantes, de raça desconhecida até então no quadro etnográfico, por um dêsses contrasensos da história, se deu o epíteto de 
indios, que ainda hoje os designa e a seus descendentes, que existem no país.

De que raça era essa gente, já foi dito no desenvolver do tema anterior, sôbre as raças do Brasil perante a ordem teológica, rural e jurídica portuguêsas.

Pode haver-se como exótica? Vocábulo advindo do grego, através do latim, exótico, no dizer dos léxicos, é o estranho, o estrangeiro, o peregrino, o que vem de fora. Não se pode, por êsse tom, haver o aborigene brasileiro como de raça exótica, por ser o autóctone, o natural do país, descendente de raça que sempre o habitou. Mas também não se ajustaria o vocábulo ao português, por ter-se a terra, então descoberta, incorporado à Coroa de Portugal, pela Bula do Papa Alexandre vi, de 4 de maio de 1493. O Brasil era terra lusitana antes de descoberto.

Tem-se entendido no entanto, no sentir de muitos, e o revela o dicionário, qualificar-se como exótico o estrangeiro, "principalmente de países estrangeiros"; e isso, por certo, do ponto-de-vista europeu.

Por êste prisma, tôda raça americana é exótica. Também a africana, uma preexistente, outra emigrada para a América.

Dessarte, ao índio, ao português e ao negro, mercê de seu cruzamento, no desenrolar do tempo, coube, nos primeiros três séculos seguintes ao descobrimento, a formação populacional do Brasil. Quase nenhum, em verdade insignificante, se revelou o contingente do francês, em suas incursões no Rio de Janeiro e no Maranhão; e do holandês, de primeiro na Bahia, depois em Pernambuco, alargando-se ao sul até às ribanceiras do São Francisco, e, ao nordeste, até ao Maranhão, no período de 1580 a 1640.

2. No exame da política de proteção e elevação das raças exóticas do Brasil, o primeiro documento, que merece destaque, é a carta de Pero Vaz de Caminha a El-rei, da Ilha da Vera Cruz, na sexta-feira, primeiro dia de maio de 1500. 
Tivesse vindo na armada de Pedro Álvares Cabral para servir como escrivão na feitoria de Calecute, ou não, não se poderia, por certo, havê-lo como simples notário.

Ciidadão do Pôrto, salientou JaIme Cortesão, êle "não era um português qualquer; mas, por definição, o mais livre e humano de todos êles. Era o português mais consciente da dignidade, que a liberdade e o trabalho conferem ao homem. E por isso o mais capaz de respeitar os outros homens. São êstes os sentimentos que dão, em grande parte, qualidade humana à carta de CAMrnha"1.

Ésses nobres sentimentos se refletiram em vários tópicos daquele notável documento, no qual se externou o alto senso político dos capitães das diversas naus, e do capitão-mor principalmente, reunidos em conselho, de que participou Pero Vaz de Caminha, o que é digno de nota, no qual se the deu a incumbência de relatar a El-rei o grande episódio da expedição.

Agudo na observação da terra e da gente, houve esta como "gente bestial"; e, por não divisar, ao alcance da vista, as choças de sua vivência, houve os índios como "aves ou alimárias monteses"; mas, sem embargo, de imensa inocência, "tal, que a de Adão não seria maior, quanto a vergonha", na sua nudez paradisíaca.

Por isso mesmo, invocou para aquela gente a proteção régia.

Segundo, escreveu o cronista, "o que a mim e a todos pareceu, esta gente não lhes falece outra coisa para ser tôda cristã, senão entender-nos, porque assim tomavam aquilo que nos viam fazer, como nós mesmos, por onde nos pareceu a todos que nenhuma idolatria, nem adoração têm. $\mathrm{E}$ bem creio que, se Vossa Alteza aqui mandar quem entre êles mais devagar ande, que todos serão tornados ao desejo de Vossa Alteza. E por isso, se alguém vier, não deixe logo de vir clérigo para os batizar, porque já então terão mais

1. Jaime Cortesão, A Carta de Pero Vaz de Caminha, Rio de Janeiro, 1943, Edições Livros de Portugal Ltda., p. 43. 
conhecimento de nossa fé, pelos dois degredados, que aqui entre êles ficam, os quais hoje comungaram ambos".

Colocou-se o problema em ponto alto, do mais justo e nobre sentimento humano.

Mas não ficou nisso o documento.

Depois de fazer a apologia da terra, "em tal maneira graciosa que, querendo-a aproveitar, dar-se-á nela tudo, por bem das águas que tem", acrescentou o cronista, reiterando o apêlo coletivo, que "porém o melhor fruto, que dela se pode tirar, me parece que será salvar esta gente. $\mathrm{E}$ esta deve ser a principal semente que Vossa Alteza em ela deve lançar".

Deu-se dessarte diretriz política para a solução do problema, que então se esboçava, a fim do aproveitamento da terra em que se haviam erguido a cruz simbólica da piedade e da civilização cristãs e o marco indelével da tomadia de posse da Terra de Vera Cruz, em nome de D. Manoel, Rei de Portugal.

3. O apêlo, assim expresso, na carta de que foi portadora a nau de GaSPAr de Lemos, destacada da frota para missão tão feliz e que tanta repercussão teria no evolver dos acontecimentos históricos, se neutralizou em simples sugestão. Provocou imenso júbilo a El-rei, como era natural; e, na comunicação que, depois do retôrno de PEDro Álvares Cabral a Lisboa, fêz aos Reis Católicos, os notificou - e foi em 28 de agôsto de 1501, de que aquêle seu capitão "com treze naus partiu de Lisboa a nove dias de março do ano passado e nas oitavas da Páscoa seguinte chegou a uma terra que novamente descobriu a que pôs nome Santa Cruz, em que achou as gentes mais como na primeira inocência, mansas e pacíficas, a qual pareceu que Nosso Senhor milagrosamente quis que se achasse porque é mui conveniente e necessária à navegação da India, porque ali corrigiu suas naus e tomou água, e pelo caminho grande que teria para andar não se deteve para se informar das cousas da dita terra, sòmente dali me 
enviou um navio a notificar-me como a achara, e seguiu seu caminho pela via do Cabo de Boa Esperança".

Não externou D. MANOEL maior contentamento a propósito do grão evento, que lhe estendia o império ao Novo Mundo, parecendo mesmo que se tratava de descobrimento comum nas avançadas de suas naus pelo mar longo, cujos mistérios pouco a pouco se decifravam.

Do Brasil, que assim se veio a chamar a terra que da Vera Cruz se batisara no ato de seu achamento, ponderou Oliveira Martins, "do Brasil, apenas descoberto, ninguém cura: são demais as terras para tão pouca gente, e o minotauro da Índia devora tôdas as fôrças e absolve tôdas as cobiças"2.

4. Feitas as expedições de reconhecimento de $1501 \mathrm{e}$ 1502, escreveu João Francisco Lisboa, "a metrópole deixou todavia passar um largo espaço sem lhe prestar a atenção que a mesma grandeza da terra parecia naturalmente solicitar de sua parte. Verdade seja que guiada pelos instintos de uma ambição vaga, e pela intuição ainda confusa da importância daquele achado, travou discussões e celebrou tratados com a Espanha para regular a partilha das vastas doações que a ambas as potências fizera a fácil liberalidade de Alexandre vi; e concedeu avultados subsídios pecuniários à França para alcançar dela que coibisse os seus armadores e corsários de infestarem aquelas paragens, aliás desertas. Mas os atos positivos para as colonizar se reduziam a muito pouco; alguns navios mandados às costas; alguns degredados postos isoladamente em terra; alguns padrões e feitorias levantadas num ou noutro ponto para autenticar a sua posse, e facilitar algum limitado comércio de pau-brasil e drogas; alguns combates enfim entre armadores estrangeiros que acudiam a partilhar os seus lucros - eis ai tudo quanto assinalam as memórias daqueles tempos. Divertido com as coisas do Oriente, cujo

2. J. P. Oliveira Martins, O Brasil e as Colônias Portuguêsas, Lisboa, 1920, Antônio Marzo Pereira, p. 6. 
brilho o deslumbrava, Portugal não quis ou não pôde então fazer mais a favor do Brasil; e foi menos o sentimento do que êle valia, que o ciúme de vê-lo ocupado por estranhos e inimigos, quem porventura o determinou, trinta anos depois do descobrimento, a intentar os primeiros ensaios de colonização com algum caráter de estabilidade"3.

A página, que acaba de ser transcrita, explica, com justeza, porque a Terra de Santa Cruz, que, no dizer de Pedro Taques, "a ambição do comércio perverteo no de Brasil, pelo interêsse do pau assim chamado"4, se achou esquecido por tão longo tempo e sujeito às incursões dos entrelopos de vária procedência européia, que desenvolveram, com o gentio, o comércio de pau de tinta.

Sem embargo, porque desgarrados ou despejados das naus em que para cá se transportaram, dois portuguêses na terra se fixaram e se entroncaram nas famílias indígenas, nelas convivendo tranqüilamente. Um foi Diogo Álvares Correia, o "Caramurú", no norte, que veio a ser de grande prestância para a edificação da cidade de Salvador, na Bahia. Outro foi JoÃo Ramalho, no sul, que facilitou a Martim Afonso de Souza, o primeiro Governador Geral do Brasil, em 1530, a execução do programa de colonização, de que o incumbiu D. JoÃo III, com a fundação da primeira vila no litoral, a de São Vicente, e outra no sertão, a de Piratininga.

Esses dois eventos demonstram que teria sido possível quiçá convivência pacífica com o aborígene, se protegido paciente e convenientemente.

5. Ainda se achava Martim Afonso de Souza, no Brasil, quando, por carta de 22 de setembro de 1532, D. JoÃo III lhe

3. Jỗo Francisco Lisboa, Jornal de Timon, em Obras de JoÃo Francisco Lisboa, S. Luiz do Maranhão, 1865, Tip. de B. de Matos, vol. III, p. 17.

4. Pedro Taques de Almeida Paes Leme, Notícias das Minas de São Paulo e dos Sertões da mesma Capitania, São Paulo, 1954. Livraria Martins Editôra S. A., p. 31. 
comunicou que "depois de vossa partida se praticou, se seria meu serviço povoar-se tôda essa costa do Brasil, e algumas pessoas me requeriam Capitanias em terras delas. $\mathrm{Eu}$ quisera, antes de nisso fazer coisa alguma, esperar por vossa vinda, para com vossa informação fazer, o que me bem parecer, e que na repartição, que disso se houver de fazer, escolhais a melhor parte, e porém, porque depois fui informado, que de algumas partes faziam fundamento de povoar a terra do dito Brasil, considerando Eu com quanto trabalho se lançaria fora a gente, que a povoasse depois de estar assentada na terra, e ter nela algumas fôrças, como já em Pernambuco começavam a fazer, segundo o Conde de Castanheira vos escrevera, determinei de mandar demarcar de Pernambuco até o Rio da Prata cinqüenta léguas de costa a cada Capitania, e antes de se dar a nenhuma pessoa,. mandar apartar para vós cem léguas, e para PERo LoPEs, vosso irmão cinqüenta nos melhores limites desta costa por parecer de pilotos e doutras pessoas de quem se o Conde por meu mandado informou, como verei pelas doações, que logo mandei fazer, que vos enviará, e depois de escolhidas estas cento e cinqüenta léguas de costa para vós, e para vosso irmão, mandei dar a algumas pessoas, que requeriam Capitanias de cinqüenta léguas a cada uma, e segundo se requerem, parece que se dará a maior parte da costa, e todos fazem obrigações de levarem gente, e navios à sua custa em tempo certo, o Conde mais largamente escreverá, porque êle tem cuidado de me requerer vossas coisas, e Eu lhe mandei, que vos escrevesse".

Molesto, evidentemente, com essa deliberação real, que à sua revelia, punha têrmo a sua missão, Martim Afonso DE Souza tratou de seu retôrno a Lisboa, deixando a Capitania, que lhe foi doada entregue a si mesma, tanto que a respectiva carta de doação sòmente lhe foi passada em 6 de outubro de 1534 e a de foral em 20 de janeiro de 1535 , quando êle já se achava em Gôa. De resto, de lá escrevendo, em 14 de dezembro de 1554, achando-se em Diu, ao Conde de Castanheira, lhe dizia que, sabendo por Pero Lopes, que 
êle queria "um pedaço dessa terra do Brasil, que lá tenho, mande-a tomar tôda ou a que quiser, que será para mim a maior mercê e a maior honra do mundo".

Sob êsse nôvo regime capitanial, com o início da política de povoamento do Brasil, daquela forma deliberada, é que se teria de estabelecer a política de proteção e elevação das raças aborigenes da grande colônia portuguêsa na América.

6. Agruparam as cartas de doações capitaniais as classes de população da colônia em três categorias - a dos nobres, a dos peões e a do gentio. Na dos peões se incluía a dos degredados e a dos criminosos homiziados. Aquela assaz se avolumou por efeito do Alvará de 31 de maio de 1535, transferindo para o Brasil o degrêdo, que antes era de S. Tomé, a que acresceu o Alvará de 5 de outubro de 1549 o que as Ordenações mandavam fazer para a Ilha do Príncipe.

Duzentos e cinqüenta e seis, observou João Francisco LisBoA, eram os casos de degrêdo estabelecidos no Livro $v$ das Ordenações, sendo cento e quarenta e dois para África, oitenta e sete para o Brasil, os mais para Castro-Mirim e outros Iugares ${ }^{5}$.

Assim dividida a população, ficando na última categoria o gentio, é de verificar qual a política que, quanto a êste, adotaram as cartas de doações.

A missão especial, observou Paulo Merêa, “dos povoadores no tocante aos indígenas tinha de ser, no espírito proselitista da época, a de trazê-los à fé cristã, mas para isso preceituavam-se meios suasórios e catequese pacífica. Nas doações e forais das Capitanias a política de assimilação não está diretamente enunciada, mas nem por isso é menos manifesta; a cada passo se faz distinção, não entre europeus e naturais, mas sim entre cristãos e gentios,

5. JoÃo Francisco LisboA, Jornal de Timon, em Obras de JoÃo Francisco Lisboa, S. Luiz do Maranhão, 1865, Tip. de B. de Matos, -v. II, p. 244. 
mostrando assim que em princípio o índio convertido e incorporado no grêmio dos colonos fica assimilado a êstes"6.

Não estava, com efeito, nos documentos institucionais das Capitanias, estabelecida a política de assimilação do gentio. Antes neles se permitia sua escravização.

"Outrossim", lê-se na carta de doação da capitania de Pernambuco a Duarte Coelho, "me praz fazer doação e mercê ao dito Capitão e Governador e a seus sucessores, de juro e herdade para todo o sempre, que dos escravos que êles resgatarem e houverem na dita terra do Brasil, possam mandar a êstes Reinos vinte e quatro peças cada ano, para fazer delas o que lhes bem vier, os quais escravos virão ao pôrto da cidade de Lisboa e não a outro algum pôrto; e mandará com êles certidões dos oficiais da dita ferra de como são seus, pela qual certidão lhe serão cá despachados os ditos escravos forros, sem dêles pagar direitos alguns, nem cinco por cento. $\mathrm{E}$ além destas vinte e quatro peças que assim cada ano poderá mandar fora, hei por bem que posso trazer por marinheiros e grumetes em seus serviços todos os escravos que quiserem e lhes fôr neceśsários".

Eis convertidos os indios escravizados em peças, o que ẻ sugestivo; e denota o espírito da época em relação a êles.

Qual salientou Paulo MerÊA, "a escravização de índios em maior ou menor número tornava-se, dadas as condições da colônia, uma triste necessidade, e a pressão dessa necessidade econômica determinava fatalmente muitos atos de violência. Os colonos não podiam nem pelo seu reduzido número nem pelas circunstâncias climatéricas dedicar-se intensivamente aos trabalhos de exploração, e quanto às raças aborígenes, afora um ou outro caso esporádico, não tinham desenvolvimento econômico capaz de fornecer trabalhadores livres. Todos os povos colonizadores, como é bem sabido, se encontravam perante o mesmo magno

6. Paulo Merêa, A Solução Tradicional da Colonização do Brasil, na História da Colonização Portuguêsa do Brasil, Pôrto, Mcmxxi, Litografia Nacional, v. III, p. 180. 
problema e todos o resolveram de igual modo, fazendo. assentar a organização do trabalho sôbre a cooperação forçada".

"A posse de escravos índios", disse página adiante, "explica-se em grande parte pelo fato de ser a instituição da escravidão conhecida e praticada pelos aborígenes. Para êstes, o prisioneiro de guerra, quando não era devorado, era reduzido à escravidão. Compreende-se assim que mesmo sem o uso da violência por parte dos portuguêses muitos escravos passassem para o poder dêstes. Freqüente era também intervirem os colonos a fim deevitar que os indigenas sacrificassem os prisioneiros, oferecendo-lhes vários objetos em troca dêles e logrando assim. resgatá-los.

"O próprio govêrno metropolitano sancionava nestas. circunstâncias a escravidão: a escravos "resgatados" se seguem, por exemplo, as doações, ao permitir, como vimos, que o capitão donatário exporte o pequeno número nelas fixado. Mas a par desta fonte há a considerar as lutas em. que os portuguêses aprisionavam indígenas e os reduziam: à escravidão por um modo não menos legítimo. Era, com efeito, doutrina corrente no tempo que os prisioneiros feitos em guerra contra os selvagens eram servos dos seus vencedores"?.

7. Sob a égide da autorização de El-rei, pelas cartas. de doações capitaniais de juro e herdade; diante da dificuldade da obtenção de braços para as lavouras, que teriam. de implantar-se nas diversas Capitanias - necessàriamente. teriam os colonizadores de buscar meio e forma de escravizar os índios, para o trabalho obrigatório, para o qual, de resto, eram inteiramente ineptos, mercê de seu nomadismo.

Iniciou-se, desde logo se diga, a escravização dos índios. com o descobrimento da América.

7. Paulo MerêA, A Solução Tradicional de Colonização do Brasil, na História da Colonização Portuguêsa do Brasil, Pôrto, Mcmxxiv, v. III, p. 180 . 
Infelizmente para o grande nome de CoLombo, disse-o João Francisco Lisboa, "foi êle o primeiro que se lembrou de prear índios, tomados em justa guerra, e de os mandar vender à Europa a troco de mercadorias, para acudir aos gastos das armadas que levava àquelas paragens. Um exemplo tão autorizado, e a grande facilidade de imitá-lo, prefizeram a resto; não só foram os índios geralmente reduzidos à escravidão, senão extenuados de trabalhos excessivos, martirizados, assassinados e quase totalmente extintos, por maneira que, segundo atesta o famoso LAS CASA, Bispo de Chiapa, de um milhão e meio que habitavam a Espaniola, à chegada dos europeus, já era difícil encontrar um ou outro, relíquias da monstruosa destruição ${ }^{8}$.

Não seria diferente no Brasil; e não foi.

Uma grande voz se ergueu contra essa escravização destruidora. Foi a do PaPa Paulo III. Chegando-lhe ao conhecimento que nas Índias, então recentemente descobertas, tanto ao ocidente, como ao meio dia, eram os respectivos indigenas tratados como brutos, e havidos por inábeis para a fé católica; e sob a capa de que eram incapazes de recebê-la, os reduziam e punham em dura escravidão, afligindo-os e oprimindo-os, em tanto extremo que ainda aquela em que traziam as suas bestas, não the era comparável - o Pontífice, em junho de 1537, expediu a Bula Universis Christi Fidelibus.

Nesse grão documento, declarou Sua Santidade, por autoridade apostólica, que os índios eram verdadeiros homens, como os mais, e não só capazes de fé cristã, senão propensos a ela, como lhe chegara ao conhecimento; e, sendo assim, tinham todo o direito à liberdade, da qual não podiam ser privados, e tão pouco do domínio de seus bens, sendo-lhes livre lográ-los e folgar com êles, como melhor lhes parecesse, dado mesmo que ainda não estivessem convertidos. Pelo que os ditos índios, e mais gentes,

8. JoÃo Francisco Lisboa, Jornal de Timon, em Obra de JoÃo Francisco LisboA, S. Luiz do Maranhão, 1865, Tip. B. de Matos, v. II, p. 276 . 
só se haviam de atrair à fé de Cristo com a pregação dax palavra divina, e com o exemplo de boa vida, sendo írrito, vão, nulo, sem valor, nem firmeza, todo o obrado em contrário daquela determinação e declaração apostólica ${ }^{9}$.

Ponderou, em seguida à transcrição e tradução dêsse notável documento, o Padre Simão de Vasconcelos, que "quando viam aquêles primeiros portuguêses um índio tapuia, um corpo nú, uns couros e cabelos tostados das injúrias do tempo, um habitador das brenhas, companheiro. das feras, tragador de gente humana, armador das ciladas e comedor de seus próprios filhos: sem Deus, sem lei, sem rei, sem pátria, sem república, sem razão - não era muito. que duvidassem se era antes bruto pôsto em pé, ou racional em carne humana".

Manifestou-se todavia em favor da causa dos índios, "porque na mesma forma que achamos possível que um homem verdadeiramente racional, por meio de criação agreste e tosco uso dos sentidos, pode perder o lustre de racional, e chegar a parecer um bruto, assim também, pelo contrário, êsse mesmo, deixando a criação agreste e tornado ao trato público dos homens, por meio dêste, poderä apurar-se e, apurados êstes, nas obras da razão".

\section{$\S 20^{\circ}$}

8. No regimento, que passou a Tomé de Souza, de $\mathbf{1 7}$ de dezembro de 1548, para o exercício da governança da Capitania da Bahia, ministrou El-rei instruções relativamente à "linhagem dos tupinambás", por ter sido informado que, "no ano de 45 estando Francisco Pereira Coutinho por Capitão da dita Bahia, alguma desta gente lhe fêz guerra e o lançou da terra e destruíu as fazendas e fêz outros muitos danos aos cristãos, de que outros tomaram exemplo e

9. Padre Simão de Vasconcelos, Crônica da Companhia de Jesus no Estado do Brasil e do que fizeram seus Filhos nesta parte do Novo Mundo, Rio de Janeiro, 1864, Tipografia de JoÃo INÁcIo DA SILvA, p. 67, n. ${ }^{\circ} 6$. 
fizeram o semelhante com outras Capitanias e que alguns outros gentios da dita Bahia não consentiram, nem foram no dito alevantamento, antes estiveram sempre de paz e estão ora em companhia dos cristãos e os ajudam; e que assim êstes que aí estão de paz, como tôdas as outras nações da costa do Brasil, estão esperando para ver o castigo que se dá aos que primeiro fizeram os ditos danos - pelo que cumpre muito a serviço de Deus e meu os que assim se alevantaram e fizeram guerra serem castigados com muito rigor. Portanto vos mando que como chegardes à dita Bahia vos informeis de quais são os gentios que sustiveram a paz e os favoreçais de maneira que sendo-vos necessário sua ajuda a tenhais certa".

Outro foi o verso da medalha.

Quando, acrescentou o regimento, "estiverdes provido do necessário e o tempo vos parecer disposto para isso, praticareis com pessoas que o bem entendam a maneira que tereis para poder castigar os culpados, o mais a vosso salvo e com menos risco da gente, que puder ser; e como o assim tiverdes praticado, o poreis em ordem, destruindolhes suas aldeias e povoações e matando e cativando aquela parte dêles que vos parecer que abasta para seu castigo e exemplo de todos; e daí em diante, pedindo-vos paz, tha concedais, dando-lhe perdão. $\mathrm{E}$ isso será porém com êles ficarem reconhecendo sujeição e vassalagem e com encargo de darem em cada um ano alguns mantimentos para a gente da povoação; e no tempo que pedirem paz, trabalhareis por haver a vosso poder alguns dos principais, que foram no dito alevantamento. E êstes mandareis por justiça enforcar nas aldeias de onde eram principais".

A palavra era mais de guerra, que de paz. Nela se reconhecia a política, até então posta em prática, da escravização do índio.

Não deixa de ser curioso entretanto relembrar que ao regimento se apôs, depois de datado e assinado um Almeirim, nota post-escrita. 
Posto que, ali se acrescentou, "em algúns capítulos dêste regimento vos mando que façais guerra aos gentios na maneira que nos ditos capítulos se contêm e trabalheis por castigardes os que fôrem culpados nas coisas passadas, havendo respeito ao pouco entendimento que essa gente até agora tem, a qual coisa diminue muito em suas culpas e que pode ser que muitos estarão arrependidos do que fizeram, haverei por meu serviço que, conhecendo êles suas culpas e pedindo perdão delas, se lhe conceda; e ainda haverei por bem que vós, para melhor maneira que puderdes, os tragais a isso, porque, como o principal intento meu è que se convertam à nossa santa fé, logo é razão que se tenha com êles todos os modos que puderem ser, para que o façais assim. E o principal há de ser excusardes fazerdethes guerra, porque com ela se não pode ter a comunicação que convém, que se com êles tenha para o serem".

Essa mudança de política teria ocorrido, depois de datado e assinado um Almeirim o regimento, da observação de que ela se divorciava fundamentalmente dos ditâmes da Bula do Papa Paulo iII.

$\mathrm{O}$ ímpeto repressor, de que ela se revestia, seria contraproducente; e ToMÉ DE SoUza ficou com poderio para examinar a situação, tanto que assumisse seu pôsto de Governador Geral da Capitania da Bahia.

9. Com o primeiro Governador Geral do Brasil, chegou, em 1549, a primeira expedição jesuítica. Chefiava-a o PAdRe MANoel da Nóbrega. Iniciou-se então trabalho, que foi incessante, de conversão do gentio, facilitada pela colaboração de Pedro Álvares Correia, o "Caramurú". Entregaramse os índios à obra da construção da cidade, de imediato começada, em regime de paz e de harmonia.

Entre abril e junho, escreveu Pedro Calmon, "reinou à roda da cidade em construção uma paz feliz, que não podia durar muito. Porque, sobrando aos portuguêses uma predisposição benévola para se entenderem com o gentio, faltava- 
lhes virtude para os não agravar. Isto é - faltavam-lhes mulheres"10.

Teriam evidentemente, de obtê-las de entre as gentias, de onde os assaltos às aldeias, que provocaram vingança, fazendo desabrochar a hostilidade dos índios e a sua revolta. E caso ocorreu mesmo em que um português, nos arredores da cidade, foi trucidado por um índio.

Feito foi êsse equiparável ao da gota determinante do transbordamento do cálice cheio.

Cá, escreveu o Padre Manoel da Nóbrega em 10 de agôsto de 1549, "é tudo papel branco e não há mais que escrever à vontade; mas é necessária a virtude e zêlo de que estas criaturas conheçam ao seu Criador e a Jesus Cristo seu Redentor. Estando pois isto nestes têrmos, o inimigo da humana geração, que estas coisas quer sempre estorvar, ordenou que a sete ou oito léguas daqui matassem um cristão dos nossos sem nenhuma razão nem causa, o que nos pôs a todos em aventura de guerra, e tomavamnos em máu tempo, e desapercebidos, e mal fortalecidos. Mas o Senhor, que do mal sabe tirar bem, quis que os mesmos negros trouxessem o matador, e o entregaram ao Governador e o puseram logo na bôca de um tiro e foi feito em pedaços".

Comentado o caso, acrescentou o grão jesuita, "isto pôs muito medo a todos os outros, que presentes estavam, e os nossos cristãos escaramentaram também de andar pelas aldeias; e foi muito serviço de Nosso Senhor por se evitar escândalo que dão aos indios os nossos que vão às aldeias"11.

Se, entre os cristãos, assim repercutiu o acontecido, mui diversa foi a repercussão entre os indios, como a história revela. Desconfiados e vingativos, êstes se puseram de

10. Pedro Calmon, História da Fundação da Bahia, Salvador, 1949, Publicação do Museu do Estado, p. 176.

11. SERAFIM Leite S. J., Cartas do Brasil e outros Escritos do P. Manoel da Nóbrega (Opera Omnia), Coimbra, 1955, por Ordem da Universidade, p. 54 , ns. 7 e 8 . 
atalaia. Não tardaria sua insurreição. Bem o disse NóBREGA. O evento "nos pôs a todos em grande aventura de guerra".

E a guerra teria por efeito, como aconteceu, a realização do princípio, que era correntio entre os doutrinadores da época, da escravização dos vencidos, feitos prisioneiros.

10. Com a investidura de MEM DE SÁ, na terceira governança geral do Brasil, atribuiu El-rei missão especialíssima, qual a de procurar, por todos os meios possiveis, trazer à fé de Cristo os índios do Brasil, desfazendo os estorvos que podiam impedir aquêle fim - o da liberdade daquela gente e quietação do Estado. Tal se dizia no regimento que lhe foi dado.

Ésse regimento, ponderou o Padre Simão de VasconcELOS, "era muito conforme ao gênio e sentimento do nôvo governador. A primeira coisa que obrou, depois de saído em terra, foi lançar bandos em favor dos índios, que fôssem postos em sua liberdade todos aquêles que, contra justiça, estavam em servidão, feitos escravos dos portuguêses, que era quantidade notável. E para o futuro, que ninguém fôsse ousado a cativar indio algum fora de guerra justa, com condições justificadas. E na execução destas leis fêz finezas".

Ademais, "publicou outras, não menos importantes; foi a primeira que nenhum dos índios nossos confederados, dali em diante, comesse carne humana (abuso ordinário) ainda que fôsse de inimigos tomados em guerra. Segundo, que nenhum principal ou comunidade fizesse guerra contra outra, senão com causa justa aprovada por êle e os de seu conselho. Terceiro, que os ajuntassem em povoações grandes a modo de repúblicas, levantassem nelas igrejas, a que acudissem os já cristãos a cumprir com as obrigações de seu estado, e os catecúmenos, a doutrina da fé, fazendo casas aos padres da Companhia de Jesus para que residissem entre êles, a fim da instrução dos que quizessem converter-se". 
Algo resultou dos apêlos assim feitos, "com a redução dos bárbaros da Bahia a quatro poderosas aldeias, de São Paulo, de Santiago, de São João e Espírito Santo, vivendo com mais polícia e acomodados aos novos preceitos"12.

11. De tal maneira se processou e desenvolveu a escravidão do índio, que o Padre Manoel da Nóbrega se viu em ponto de protestar contra a que se realizava por via do "resgate", o que originou a Lei de 20 de março de 1570. D. Sebastião, "por motivos de consciência", restringiu a escravatura de indios no Brasil.

"Defendo e mando", disse El-rei naquele documento, "que daqui em diante se não use nas ditas partes do Brasil dos modos que se até ora usou para fazer cativos os ditos gentios, nem se possam cativar por modo nem maneira alguma, salvo aquêles que forem tomados em guerra justa, que os portuguêses fizerem aos ditos gentios, com autoridade e licença minha, ou do meu governador das ditas partes, ou aquêles que costumam saltear os portuguêses, ou a outros gentios para os comerem; assim como são os que se chamam Aimorés e outros semelhantes".

Distinguiu-se dessarte a escravidão, em duas categorias. Uma era a lícita. Outra, a ilícita.

Os que, lìcitamente cativassem os gentios, eram obrigados, a fazer "escrever os tais gentios cativos nos livros das Provedorias das ditas partes, para se poder ver e saber quais são os que licitamente foram cativos. E não o cumprindo assim no dito tempo de dois meses: heî por bem que percam a ação dos ditos cativos e senhorio. E que por êsse mesmo motivo sejam forros e livres. $E$ os gentios que por qualquer outro modo e maneira forem cativos nas ditas partes declaro por livres, e que as pessoas que os cativaram não tenham neles direito nem senhorio algum ${ }^{13}$.

12. PadRe Simão de VAsconcelos, Vida do Venerável Padre José de Anchieta, Pôrto, 1953, Lello \& Irmão, Editores, p. 68, ns. 3 a 7.

13. Waldemar Ferreira, História do Direito Brasileiro, São Paulo, 1952, Livraria Freitas Bastos, S. A., vol. II, p. 137, n. 91. 
Foi essa quiçá a primeira providência legislativa destinada à proteção da raça indígena.

Posto se houvesse admitido a escravização do gentio aprisionado em guerra justa - tal a aprovada por El-rei ou pelo seu governador geral do Brasil - com o estabelecimento do registro dos escravos assim, o que parece não ter entrado em execução, a não ser em casos especialíssimos, é de crer (e não poucos historiadores o afirmaram) que a determinação legislativa de certo modo amainou a escravatura indigena com aquêle fundamento.

Mais favorável ainda à liberdade, e assim se manifestou João Francisco Lisboa, por lei de 11 de novembro de 1595, D. Felipe, II de Castela e I de Portugal, revogando aquela lei, mandou que "em nenhum caso fôssem os índios cativos, salvo sòmente os que se tomassem em guerra mandada fazer expressamente por provisões particulares assinadas por El-rei; porquanto tinham vindo a seu conhecimento os meios que os moradores do Brasil usavam para os cativar sob pretexto de justa guerra"14.

12. Existiam, ao tempo do Padre Nóbrega, escravos negros no Brasil; e era natural, porque de há muito, o tráfico negreiro era comércio livre em Portugal, alcançando tôda a Península. Iniciara-se com a descoberta do arquipélago de Arguim, em 1443, por Nuno Tristão. Então, observou Nunes Dias, Portugal começou a organizar em sólidas bases os resgates do ouro, dos escravos e dos demais produtos africanos da primeira rota atlântico ${ }^{15}$. Começou-se então o tráfico dos escravos negros, pelos resgates. $\mathrm{E}$ isso pelo benefício "de os resgatar de morte certa ou do cativeiro dos seus inimigos", como diziam velhos documentos. Escravos, por escravos, melhor seria que o

14. JoÃo Francisco LisBOA, Jornal de Timon, nas Obras de JoÃo Francisco Lisboa, S. Luiz do Maranhão, 1865, Tip. de J. B. DE Matos, v. II, p. 279.

15. Manom Nunes Dias, O Capitalismo Monárquico Português (1415-1549), Coimbra, 1863, v. I, p. 424. 
fôssem dos europeus, dos ibéricos em especial. Assim na Europa. Por igual, na América.

Depois, escreveu NóBrega, em carta de agôsto de 1552, "que vieram os escravos d'El-rei, de Guiné a esta terra, tomaram os Padres fiados por dois anos três escravos, dando fiadores a isso, e acaba-se o tempo agora cêdo. Desta vestiaria fiz mercar outros escravos da terra"16.

Sem embargo, referiu Perdigão Malmeiros, que "o Padre MaNOEl da Nóbrega, pouco depois da fundação, em 1594, da Bahia, cabeça do Estado, no govêrno de Tomé DE SouzA, escrevia ao Padre Prepósito, do Colégio de Santo Antão em Lisboa, queixando-se dessa introdução de escravos negros e negras na nova povoação, inoculando-se assim no Brasil o fatal câncro da escravatura, fonte de imoralidade e de ruína ${ }^{17}$.

Ao entender de Varnhagen, "os escravos africanos foram trazidos ao Brasil desde a sua primitiva colonização; e naturalmente muitos vieram, com seus senhores, a bordo dos primeiros navios que aqui aportaram, compreendendo os da armada de Cabral. Porém, a verdadeira introdução dos escravos de Guiné, e depois de quase tôda a África, isto $\dot{e}$, do tráfico em ponto maior, proveio, em primeiro lugar como ficou dito, de se haver promulgado como ilegal a escravatura índia, com raras exceções, das quais se os poderosos abusavam, outros se receavam, só por não virem a achar-se no caso de ter que pleitear o seu direito. Em segundo lugar, proveio de se haver já nas Antilhas conhecido por experiência que os africanos eram mais fortes, e resistiam mais ao trabalho aturado do sol do que os índios".

De resto, e muito mais que o índio escravo, o escravo africano era objeto comerciável, percebendo a Coroa a

16. Serafim Leite, S. J., Cartas do Brasil e outros Escritos do P. Manoel da Nóbrega (ópera Omnia), Coimbra, 1955, por Ordem da Universidade, p. 140 , n. 4.

17. Agostinho Marques Perdigão Malheiro, A Escravidão no Brasil; Ensaio Histórico-Jurídico Social, São Paulo, 1944, Edições Cultura, v. II, p. 20. 
sisa de sua negociação. Informou, de resto, o historiador que "o direito de sisa dos escravos foi na metrópole rematado por contrato, e a um pedido de Duarte Coelho para introduzir livres certo número dêles, respondeu-lhe o rei que não lhe podia dar, enquanto o prazo de tal contrato não expirasse" 18 .

Nem só isso poderosamente contribuíu para que as duas escravaturas - a do índio e a do negro africano, paralelamente se desenvolvessem, a dêste com maior amplitude, de modo a, com o tempo, sobrepujá-la, perdurando mais longamente.

A raça africana - e é de reproduzir-se sugestiva página de Sílvio Romero - "tem tido no Brasil uma influência enorme, sòmente inferior à da raça européia; seu influxo penetrou em nossa vida íntima e por ela moldou-se em grande parte nessa psicologia popular. É fácil compreendêlo. A raça africana entre nós, ainda que não dirigida por um impulso próprio, deve também ser contada como raça invasora, e esta circunstância merece atenção. O português

18. Visconde de PôRto Seguro, História Geral do Brasil antes de sua separação e Independiencia de Portugal, São Paulo, s/d., 4.a ed. da Companhia Melhoramentos de São Paulo (Weisflog Irmãos Incorporados) Editora-Proprietária, v. I, p. 279.

Em carta de 27 de abril de 1542, DuARte CoklHo expôs a El-rei que, "porque para coisas de tanta importância hás mister muitos grandes gastos e eu estou muito gastado e individado e não poder sofrer tanta gente de sôldo, como até aqui sofri, e já três anos que pedi a v. A. me fizesse mercê de me dar licença e maneira de haver alguns escravos da Guiné, por meu resgate; e o ano passado me saíu que até não se acabar o contrato que era feito, não se podia fazer, dando-me a entender que, como fôra acabado, seria provido, pelo qual já lá escrevi a B. A. sôbre isso, não sei se me fez essa mercê, porque os navios não são ainda vindos - peço a v. A. que, se não me proveu desta licença, que olhe quanto seu serviço isto é, quão pouco dano, nem estôrvo, faz dar-me licença para haver algumas peças de escravos, para o melhor servir e a DOM PEDRo DE MOURA e MANOEL D'AlbuQUeRQue, que mande Vossa A. dar a provisão para isto" (História da Colonização Portuguêsa do Brasil, Pôrto, McmxxIv, Litografia Nacional, v. III, p. 314). 
julgou-se fraco para repelir o selvagem e para o amanho da terra, e recorreu a um auxiliar poderoso - o negro da África. Ao passo que o índio tornava-se improdutivo, fugia, esfacelava-se e morria, durante mais de três séculos foram chegando levas e levas de africanos robustos, ágeis e domáveis, e foram fundando as fazendas e engenhos, as vilas e as cidades. permanecendo no seio das familias coloniais. $O$ índio, em geral, foi um ente que se viu desequilibrado e feneceu; o negro, um auxiliar do branco, que prosperou. Acresce que o número de africanos transportados ao Brasil, durante mais de trezentos anos, foi muito superior à população cabocla primitiva. Computam-se em milhões, e tôda essa gente válida e fecunda fêz prosperar o país. O próprio fato da escravidão serviu para ainda mais vincular os prêtos aos brancos. As escravas, e raro era o colono que não as tinha, viviam no seio das famílias no serviço doméstico. Daí o cruzamento natural; apareciam os mestiços e novos Jaços se criavam"19.

13. Do que até agora foi exposto se infere que, no primeiro século da vida brasileira, o décimo-sexto da era cristã, e vale dizê-lo por palavras de João Francisco LisboA, "a raça européia atuou sôbre a indigena por muitos e variados modos - pelas leis de escravidão e liberdade, e, na execução destas, por meio dos chamados resgastes e descimentos, pela catequese religiosa enfim, não menos que pelas guerras incessantes e prolongadas que se travaram desde os primeiros tempos da descoberta".

Dêsse modo avulta, sem dúvida, a ação dos jesuítas. A Coroa, nesse particular, se mostrou vacilante; mas o pelotão do Padre Manoel da Nóbrega não vacilou nunca na sua missão catequética e colonizadora, fiel e resoluto na execução do programa de seu grande chefe. Traçou Nóbrega, desde logo, a política de proteção e elevação da raça indigena.

19. Sílvio Romero, História da Literatura Brasileira, Rio de Janeiro, 1902, H. GARNIER, Livreiro-Editor, จ. I, p. 90. 
Resumiu-a o Padre Serafim Leite em poucas linhas, que não podem ser olvidadas, dizendo que, "perante a História, MEM dE SÁ é o chefe civil e militar, Nóbrega um como secretário de Estado. Com o braço de um e o conselho de outro, o Brasil perturbado e cortado ao meio na baía de Guanabara se iria na verdade unir e pràticamente constituir em bases perduráveis. Mas, como sempre, em primeiro lugar, os índios. Era preciso civilizá-los, verbo que nos dicionários, tratando-se de nações ainda incultas, se chama colonizar. Colonizar o Brasil significava transformar brejos em campos cultivados, erguer cidades onde crescia o mato, educar os povos naturais e de costumes selvagens, como era no Brasil, por exemplo, o comer carne humana. Barbaridade, que ainda se usava às portas da Bahia e estava vivo na memória de todos o que havia sucedido pouco antes à nau do Bispo.

“O plano colonizador de Nóbrega expõe-no êle no seu apontamento de 8 de maio de 1558.

"A lei que lhes-hão de dar é:

1, defender-lhes comer carne humana, e guerrear sem licença do governador;

2, fazer-lhes ter uma só mulher;

3 , vestirem-se, pois têm muito algodão, ao menos depois de cristãos;

4, tirar-lines os feiticeiros;

5, fazê-los viver quietos, sem se mudarem para outra parte se não fôr para entre os cristãos, tendo terras repartidas que lhes bastem e com êstes Padres da Companhia para os doutrinar.

"É a civilização nos seus aspectos fundamentais: combate à antropofagia e semi-nomadismo indígena; o estabelecimento da monogamia e do trabalho agrícola; a autoridade civil e a educação cristã"20.

20. SeRAfim Leite, S. J., Breve Itinerário para uma Biografia do P. Manoel da Nóbrega, o Fundador da Província do Brasil e da Cídade de São Paulo, Lisboa e Rio de Janeiro, Edições "Broteria" e Livros de Portugal, p. 129, n. 3. 
Esta educação, destinada à elevação da raça indígena, se iniciou desde logo. Se Tomé de Souza se entregou à obra de construção da cidade, NóBrega se devotou, colaborando com êle, à da construção do Colégio, o primeiro estabelecimento de ensino - a Casa do Nome de Jesus, que depois foi o Colégio dos Meñinos de Jesus, ao qual se seguiu o dêste mesmo nome, em São Vicente, inaugurado por Nóbrega aos 2 de fevereiro de 1553.

Ao que escreveu Anchieta, em 1555, em São Paulo existia colégio freqüentado por bom número de estudantes, brancos e mamelucos, que acudiam das aldeias circunvizinhas, bem assim indios e filhos dêstes.

Êsse Colégio, o Colégio de São Paulo de Piratininga, se constituíu então canônicamente; e, por êsse prisma, se pode dizer, e o Padre Serafim Leite o disse, foi o primeiro do Brasil.

Infelizmente, êsses moços, com o contacto com os de fora, an vir a crise da idade, juntando-se ao pendor da natureza o ambiente ancestral, ainda não purificado, deram no que disse José DE ANCHiEta: "chegando aos anos da puberdade, começaram a apoderar-se de si, vieram a tanta corrupção, que tanto excedem agora a seus pais em maldade, quanto antes em bondade, e com tanta maior sem-vergonha e desenfreamento se dão às borracheiras e luxúrias, quanto com maior obediência e modéstia se entregavam dantes aos costumes cristãos e divinas instruções".

Não sem melancolia, referiu que haviam trabalhado "muito com êles para os reduzir ao caminho direito, nem nos espanta esta mudança, pois vemos que os mesmos cristãos procedem da mesma maneira"21.

Empenharam-se os jesuitas não apenas em proteger os índios, no exercício de seu alto ministério, mas sobretudo

21. SeRAfim LeIte, S. J., História da Companhia de Jesus no Brasil, Lisboa e Rio de Janeiro, 1938, Livrairie Portugalia e Civilização Brasileira, v. I, p. 291. 
de os elevar, dando ensinamentos a seus filhos, de molde a introduzí-los na normalidade de vida cristã.

Não pareceu bem a MANOEL da Nóbrega a mudança. Explicava "a defecção dos moços índios com o costume, que tinham os pais, de mudarem de terra, o tempo que lhes dura a casa de palha; e depois mudam para outra, de mais a mais dispersos; e, ao retirarem-se, levavam os filhos, ficando êstes longe das vistas dos padres e da indispensável assistência religiosa. Por isso, a muitos sucedeu o que escreveu Anchieta; mas, para alguns, o recuar foi aparente. Não vinham à missa, conclui NóBREGA, porque, andando agora nus e, estando habituados com os padres a andarem vestidos, tinham vergonha"

É expressivo o fato, em si mesmo. Demonstra que os indios, como foi reconhecido pelos jesuitas, não podiam, por empedernidos por sua indigência intelectual, compreender e sentir a doutrina cristã, que se tentava inocular em seus espíritos primitivos e de rústica animalidade.

Mas os jesuitas eram convictos de que a graça divina poderia operar o milagre da conversão do gentio.

\section{$\S 3 .^{\circ}$}

14. Ao iniciar-se o século xvir, o problema da escravatura indígena permaneceu na mesma situação, a despeito da lei da liberdade dos índios, de 26 de julho de 1596.

Houve grandes embaraços e dúvidas de consciência nos que tiveram de a cumprir.

Recorreu-se, no relato do Padre Simão de Vasconcelos ao Tribunal da Mesa da Consciência, em Lisboa; e dêle veio a resolução seguinte: "que o pai podia em direito vender os filhos em caso de apertada necessidade; e que qualquer se podia vender-se a si mesmo para gozar do preço. Havida esta resolução, entraram em consulta na cidade da Bahia o Bispo D. Pedro Leitão com o Governador Mem de Sá, o Ouvidor Geral Braz Fragoso e o Padre 
Provincial Luíz da Gram: e pareceu bem que se publicasse ao povo a resolução da Mesa da Consciência, porque com ela ficassem quietos os que compraram na forma conteúda, e os que foram comprados fora dela se tivessem por livres. Porém, como os moradores da Bahia, e de tôda a costa, estavam feitos senhores de tão grande quantidade de índios vendidos fora do direito por tios, e irmãos, e parentes, que não tinham domínio sôbre êles, determinou-se que os tais eram livres. Vistas contudo as grandes dificuldades que se alegavam de se largarem todos êstes índios do serviço dos portuguêses; e porque podiam ir outra vez meter-se entre os gentios, com dispêndio de suas almas, e não sem perigo da república, foi permitido que ficassem em casa dos que tinham com as condições seguintes: que os ditos indios assim mal havidos fôssem avisados de sua liberdade; mas que como livres servissem àqueles que os resgataram em suas vidas, por evitar os inconvenientes que do contrário se podiam seguir; e que, fugindo os tais índios, os pudessem os amos mandar buscar, e castigar, e com condição que os amos, em reconhecimento de sua liberdade, lhes pagassem em cada um ano por seu serviço aquilo que justamente lhes fôsse taxado, com declaração, que continuando êles a fugir para o gentio, sendo depois da primeira vez, perdessem a soldada de um ano, em recompensa do que os amos perderam em buscá-los. E outrossim que os possuidores dos ditos índios os não poderiam vender, nem dar, nem trocar, nem levar fora do Brasil e o que os não quizesse possuir com as condições apontadas, os pudesse dar aos que lhes venderam, sem título de dominio que tivessem sôbre êles, e êstes lhes tornassem o preço".

Era a liberdade do índio dessarte puro eufemismo. Deu-se à lei interpretação que lhe contradizia os têrmos e até instituía o direito de retrovenda em favor de quantos não se dispuzessem adotá-la.

Nem estas condições, obtemperou o historiador, se guardaram, "nem a resolução serviu de mais que de cativarem mais índios com capa de vendidos por si mesmos, 
ou por seus pais, porque enganavam os pobres, e quando iam os registrar, faziam que dissessem o que queriam, sendo que (tirando poucos na fôrça de fome sobredita) se achará que índio se vendesse a si, ou a filho legítimo: nem suas necessidades são tais, que se não possam remediar sem semelhante rigor de vendas, contrárias à liberdade natural, tão estimada dêles, e de todos os homens. Nem também a condição permitida do serviço dos índios para tôda a vida, posto que, por seu estipêndio, deixava de ser violento, e quase modo de cativeiro, a não intervirem gravíssimas razões verdadeiras, que a conestassem"22.

15. Originaram tais deliberações as Provisões de 5 de junho de 1605 e 4 de março de 1608, favoráveis à obra catequista jesuítica e a Lei de 30 de julho de 1609, pela qual se revogou tôdas as leis anteriormente passadas sôbre a liberdade do indígena, declarando "todos os índios do Brasil", na referência do mesmo historiador, "assim batizados, como por batizar, por livres, conforme o direito, e nascimento natural; e manda que por tais sejam tidos e havidos; e acrescenta assim. E por quanto sou informado, que em tempo de alguns governadores se cativaram muitos gentios contra a forma da lei d'El-rei, meu Senhor e Pai: hei por bem, e mando, que todos sejam postos em sua liberdade, e se tirem logo do poder de quaisquer pessoas que os tiverem, sem embargo que digam que os compraram, e que por cativos lhes foram julgados por sentenças, as quais compras e sentenças declaro por nulas, por serem contra direito. A qual lei, suposto que se veio com embargos na cidade da Bahia à execução, e se replicou a Sua Magestade, não obstante os embargos e réplica, se tornou a passar outra em 10 de setembro de 1610, em que confirma a passada. E ùltimamente esta mesma foi confirmada por El-rei D. Felipe Iv, passada em Lisboa em

22. Simão DE VAsconcelos, Crônica da Companhia de Jesus do Estado do Brasil, Rio de Janeiro, 1864, Tipografia de JoÃo INÁcio DA Silva, Livro I, p. 192, ns. 41 e 42 . 
31 de março de 1670, e registrada na Bahia no mesmo ano, em que manda que nenhum indio de qualquer qualidade, ainda que seja infiel, possa ser cativo, nem posto em servidão, por nenhum modo, causa, ou título, nem possa ser privado do domínio natural de seus bens, filhos, ou mulher, agravando apertadamente as penas passadas, como ai se pode ver".

Decretou-se dessarte a plena abolição da escravatura indigena, nos mais amplos têrmos. Foi aquela lei registrada em tôdas as Capitanias do Brasil. Contra ela se rebelaram os colonos e a Câmara da Bahia, sob o fundamento de que era "notável desserviço de Deus e de Sua Majestade, e prejudicial a todo êste Estado". A campanha, que então se desenvolveu pela mantença da escravidão indígena, se tornou vitoriosa. A lei de 10 de setembro de 1611 voltou à ressurreição da de 1570, de D. Sebastiáo. Confirmavam a liberdade dos índios. Como escreveu o Padre Serafim Leite, não obstante "admitiam-se os cativos em guerra justa, ou resgatados de morte. Proibia-se a guerra contra os indios, mas permitia-se, sendo atacados por êles. Neste perpétuo debate sôbre a escravidão dos índios, tanto El-rei, como os jesuitas, representavam o que hoje se chama oposição. Na realidade a opinião pública do tempo queria e exigia a escravidão dos índios" 23 .

23. Serafim Leite, S. J., História da Companhia de Jesus no Brasil, Rio de Janeiro, 1945, Imprensa Nacional, v. V. p. 8.

Como se vê, foram diversas, e até contraditórias, as providências legislativas sôbre os índios.

Ao que escreveu JoÃo Francisco LisboA, "as datas que se seguem indicam outras tantas providências legislativas sôbre os indios, promulgadas durante quase três séculos, desde D. SEBAstião até nossos dias, sob a denominação de leis, cartas régias, provisões, alvarás, éditos, decretos, regimentos e diretórios, a saber: 20 de março de 1570, 22 de agôsto de 1577, 11 de novembro de 1595, 25 de julho de 1516, 5 de julho de 1605, 7 de março e 30 de julho de 1609, 10 de setembro de 1611,15 de março de 1624,8 de julho de 1625,10 e 12 de novembro de 1647,5 e 29 de setembro de 1648,12 de setembro e 21 de outubro de 1652,12 de julho de 1653, 12 de setembro e 18 de outubro de 1663, 29 de abril de 1667, 21 de novembro de 1673, 23 de janeiro de 1671, 
16. Já em 1653, em carta a El-rei, o PadRe Antôniơ VIEIRA, se havia manifestado a propósito.

"O remédio que Vossa Majestade, Senhor, e os senhores reis anteriores de Vossa Majestade procuraram dar a esta tirania, foi mandar cerrar totalmente os sertões, e proibir que não houvesse resgates, e declarar por livres a todos os já resgatados, de qualquer modo que o fôssem. Êste remédio, Senhor, verdadeiramente é o mais efetivo de quantos se podem representar, mas é dificultosíssimo e quase impossível de praticar, como a experiência tem demonstrado, em: todos os tempos, e muito mais nos motins dêste ano, fundados todos em serem os índios o único remédio e sustentor dos moradores, que sem êles pereceriam. O meio queparece mais conveniente e praticável (como já se tem começado a executar) é examinarem-se os cativeiros, eficarem livres os que se acharem livres, e cativos os que se acharem cativos".

Não restou o grande orador, tornado missionário no setentrião brasileiro, nos últimos tempos de sua vida, adstrito à mantença da situação existente. Bateu no ponto atinente aos resgates. Quanto a êste, "para o futuro, se se houverem de fazer entradas só a êsse fim, será dar outra:

31 de março e 1 de abril de 1680, 2 de setembro de 1684, 21 de dezembro, de 1686 (são duas as disposições desta data, uma carta régia e o. famoso regimento das missões), 24 ou 28 de abril de 1688,6 e 17 de janeiro de 1691, 19 de fevereiro e 15 de março de 1696, 15 de janeira de 1698, 11 de janeiro, 1 e 8 de fevereiro de 1703, 6 de dezembro de 1705,5 de julho de 1715,9 de março de 1718,12 de outubro de 1719 , 12 de outubro de 1727,13 de agôsto de 1745 , 13 de outubro de 1751, 13 de agôsto de 1745, 13 de outubro de 1727, 13 de agôsto de 1745, 13 de outubro de 1751, 4 de abril, 6 e 7 de junho de 1755, 3 de maio de 1757,8 de maio e 17 de agôsto de 1758,11 de maio de 1774, 12 de maio de 1797, 18 de agôsto de 1803, 13 de maio e 2 de dezmbro de 1808 e 28 . de julho de 1809.

"A esta imensa e complicada legislação portuguêsa acrescem ainda as Bulas dos Papas PaUlo III, URbano viII e Benedito XIV sôbre o' mesmo assunto da conversão e liberdade dos índios". (João Francisco LISBOA, Jornal de Timon, em Obras de JoÃo Francisco LisbOA, S. Luiz do Maranhão, 1865, Tip. de B. de Matos, v. II, p. 274). 
vez nos mesmos inconvenientes. Mas porque convém que haja os ditos resgates, ao menos por reunir aquelas almas, o modo com que se podiam fazer justificadamente, é êste: que as entradas do sertão se façam só a fim de ir converter os gentios e reduzí-los à sujeição da Igreja e da Coroa de Vossa Majestade (como Vossa Majestade me tem ordenado) e que, nessas entradas se acharem alguns índios em cordas ou legìtimamente escravos, que êsses se possam comprar e resgatar, aprovando-o primeiro os padres que forem à dita missão"24.

Era dessarte unânime a convicção de que o aprisionamento e cativeiro dos índios não podiam ser dispensados, ora por um, ora por outro fundamento.

Assumiria o problema dessarte, no século xvir, aspecto. imprevisto, no sul do país.

Se a primeira entrada pelo sertão foi ordenada por Martim Afonso de Souza, comandada por Pero Lôbo e guiada por Francisco Chaves, com o insucesso que a história registra, êste não impediria, como não obstou, a que outras se fizessem mais tarde, não sòmente para imposição ao gentio do respeito ao rei de Portugal, como para satisfação. do interêsse dos próprios colonos, carecedores de braços para o amanho e cultivo da terra.

De nada valeram, ponderou Afonso de TAunay, "as cartas régias de D. Sebastião, de 1570 , a proibirem a escravização dos índios, legislação que os colonos bem sabiam ser decretada para constituir letra morta. A escapatória da "guerra justa" trazia a automática revogação das ordens. reais" 25 .

17. Ao que referem vetustos documentos, e observou Buarque dE Holanda, "não foi uma civilização tìpicamente agrícola a que instauraram os portuguêses no Brasil com

24. J. LÚCio DE Azevedo, História de Antônio Vieira, Lisboa, 1931, Livraria Clássica Editôra de A. M. Teixeira \& Cia. (Filhos), v. I, p. 226.

25. Afronso de Taunay, História das Bandeiras Paulistas, São Paulo, s/d., Edições Melhoramentos, v. I, p. 21. 
a lavoura açucareira. Não o foi, em primeiro lugar, porque a tanto não conduziria o gênio aventureiro que o trouxe à América; em seguida, por causa da escassez da população do Reino, que permitisse imigração em larga escala de trabalhadores rurais, e finalmente pela circunstância de a atividade agrícola não ocupar então, em Portugal, posição de primeira grandeza" 26 .

Se o primeiro engenho de cana se instalou em São Vicente, no planalto de São Paulo de Piratininga a indústria açucareira não teve surto, em razão de seu clima. Impediram-no o frio e a geada. Mas nessa Capitania nem ao menos o pau de tinta, de que os moradores alcançaram grande proveito, se produzia. É que, e Pero DE Gandavo observou, êsse pau se "mostra claro ser produzido de quentura do sol, e criado com a influência de seus ráios, porque não se acha senão debaixo da tórrida zona, e assim quanto mais perto está da linha equinocial, tanto é mais fino e de melhor tinta; e esta é a causa porque o não há na Capitania de São Vicente nem daí para o sul"27.

26. SÉrgio Buarque de Holanda, Raízes do Brasil, Rio de Janeiro, 1956, Livraria José Olympio Editôra, p. 45.

No mesmo ano, prosseguiu o autor, "de 1535, em que DuARte Coklho desembarcava em sua donatária pernambucana, o humanista Clenardo, escrevendo de Lisboa a seu amigo Latônıo, dava notícia das miseráveis condições em que jaziam no país as lides do campo: "Se em algum lugar a agricultura foi tido em desprêzo - dizia - é incontestàvelmente em Portugal. E antes de mais nada, ficai sabendo que o que faz o nervo principal de uma nação é aqui de uma debilidade extrema; para mais, se há algum povo dado à preguiça sem ser o português, então não sei onde êle exista. Falo sobretudo de nós outros que habitamos além do Tejo e que respiramos de mais perto o ar da Äfrica". E algum tempo mais tarde, respondendo às críticas dirigidas por SEBASTIÃo MÜNSTER aos habitantes da península hispânica, DAMIĀo DE Góis admitia que o labor agrícola era menos atraente do que as aventuras marítimas e as glórias da guerra e de conquista" (M. GonçALves 'Cerejeira, o Humanismo em Portugal, Clenardo, Coimbra, 1926, p. 271).

27. Pero dn Magalhães Gandavo, História da Província de Santa Cruz, Rio de Janeiro, s/d., Edição do Anuário do Brasil, p. 99. 
Por isso, e ademais porque isolados do resto do mundo pelas dificuldades de comunicação, mas sobretudo diante da deficiência de braços para a lavoura e atendimento de suas necessidades domésticas, se sentiram os moradores da Capitania na emergência de obtê-los a todo o transe.

Houveram, por isso, e Washington Luís ponderou, de "entrar ao sertão, estendendo a costa do Brasil (como então se dizia) desde o oceano até o interior desconhecido, revelando os seus territórios, ou então a colonização portuguêsa do Brasil teria desaparecido sem deixar vestígios, como a esteira pouco rumorosa duma canôa solitária, que sulca águas dormentes. Esse devassamento traria as inevitáveis guerras com o gentio. As guerras ou o abandono da colônia: o dilema se apresentava inexorável. Diante dessa alternativa, os moradores da Capitania de São Vicente preferiram duramente, violentamente permanecer, e para isso era necessário escravizar ou exterminar, "conquistar ou ser conquistado; era preciso optar entre essas duas condições extremas, não restando nenhum partido intermediário" (como pensaria TAINE). Mas os portuguêses encontraram ainda um partido intermediário - o cruzamento" 28 .

18. O sertão era realmente o grande enigma. Instava decifrá-lo. Foi o a que se propuseram os moradores de São Paulo, cônscios dos riscos e das dificuldades, de vária ordem, que teriam de enfrentar e vencer. Se, por todos os modos, incentivava a metrópole as iniciativas em busca das minas de ouro e de prata, que deveriam jazer nas entranhas da terra que entestava com as do Perú, o que mais preocupava os paulistas, em razão de seu resultado imediato, era o preamento do índio, tanto para o povoamento de seu planalto, quanto para a abertura das lavouras que fôssem possiveis.

A entrada ao sertão teria que fazer-se, para êsse objetivo. Como o empreendimento era difícil e arriscado, para

28. Washington Luís, Na Capitania de São Vicente, São Paulo, 1956, Livraria Martins Editôra, p. 168. 
efetuá-la houveram os paulistas que organizar-se, devidamente, com recursos monetários, pessoal disposto, meios de subsistência no percurso que sòmente se sabia quando se iniciaria, não quando, onde e como terminaria. Ademais, armas e munições. Era, dessarte, autêntica expedição, senão mesma verdadeira emprêsa. Ou seja a bandeira ${ }^{29}$.

O escopo dos que a organizavam, ou dela participavam, era utilitário, quiçá de evidente natureza mercantil, pelo interêsse de seus componentes na partilha das peças, ou indios, com que seriam aquinhoados, ao regresso, que, como escravos, seriam retidos, quando não negociados na Capitania de São Vicente ou nas mais próximas, como a do Rio de Janeiro.

O século xvir foi dessarte o da era do bandeirismo, que deu ao problema da escravização do gentio nôvo aspecto e Euclides DA CUNHA houve como "tradição heróica", que constituíu "o único aspecto original de nossa história".

Mas o bandejrismo não foi sòmente preador de índios. Para preá-los, tiveram os bandeirantes que fazer sua caminhada a dentro do sertão, ảbrindo nele picadas que se converteriam em caminhos de comunicação. Nas estâncias da jornada, abriram-se clareiras. Fincaram-se cruzes. Levantaram-se capelas. Construiram-se aldeias de casas toscas. Estabeleceram-se culturas. Criou-se o gado. De onde em onde se instalaram pousadas; e com isso o território se foi alastrando por essa ocupação transitória, deixando atrás as fronteiras e imaginárias linhas da divisão castelhana. Conquistou-se o sertão.

Com a descoberta do ouro, o bandeirismo se transfigurou. Deixou de ser nômade, em certo sentido, pois que a cata aurifera exigia instalação adequada. Mas nem por isso impediu que as bandeiras de terra e as monções fluviais marcassem, com as descobertas do ouro, novos pontos de apossamento e de estância, alargando no espaço o predomínio da Corôa lusitana.

29. Waldemar Ferreira, História do Direito Brasileiro, São Paulo, 1956, Max Limonad, Editor, v. Iv, p. 23 a 105. 
Coincidiu, com êsse evento histórico, o das invasões de franceses e de holandeses, que foram sustadas, detidas e vencidas, no Rio de Janeiro, na Bahia, em Pernambuco, no Maranhão, consolidando-se o domínio de Portugal em sua colônia sul-americana. Configurou-se êste então geogràficamente, quer pela expulsão dos invasores, quer pela definitiva conquista do sertão.

Tôda essa arremetida, assim no interior, como no litoral, não removeu, nem ensejou solução adequada à proteção e elevação de índios e prêtos, que continuaram subjugados pela escravidão.

19. Dividida a colônia portuguêsa, em 1612, por cissiparidade, com a separação do Estado do Maranhão (Ceará, Piauí, Maranhão, Pará e depois Amazonas) do Estado do Brasil, aquêle se tornou independente dêste e ambos sujeitos diretamente a Lisboa.

No Estado do Maranhão, o problema da escravidão de indio "adquiriu solução específica, que é de assinalar. Ocorreu a D. JoÃo IV restabelecer ali a Companhia de Jesus, destacado o PADre Antônio Vieira para o grande cometimento. Impressionou-o a condição dos índios. Seguiam, êle o disse, “os portuguêses do Maranhão e Pará a mesma carreira de opressão que nas costas das Capitanias mais antigas exterminara os índios. Permitia a lei que fôssem os escravos os naturais capturados em justa guerra, e também os que, tendo sido aprisionados uns pelos outros, houvessem sido comprados pelos portuguêses, chamando-se êstes últimos, como tendo sido destinados a serem comidos, indios de corda, em alusão à muçurana. Daqui nasciam necessàriamente todos os inumeráveis males de um regular tráfico de escravos"30.

Obteve o jesuíta, por Carta Régia de 21 de outubro de 1652, ampla autorização para estabelecer missões, levantar

30. Padre Raphael M. Galanti, S. J., Compêndio de História do Brasil, São Paulo, 1902, Tip. a Vapor de Duprat \& Cia., v. II, p. 410, n. 353 . 
igrejas, descer índios ou deixá-los em suas aldeias "como então julgardes por mais necessário à sua conservação", obrigando tôdas as autoridades a lhe darem "tôda a ajuda e favor que pedirdes, assim de indios, canoas, pessoas práticas na terra, e línguas, como do mais que vos fôr necessário".

No capítulo do regimento, dado a Baltazar de Souza Pereira, despachado, em 1652, Capitão-mor do Maranhão, se lhe deu ordem para pôr em liberdade todos os índios que aquêle tempo tivessem vivido como escravos.

Disso resultou a sublevação do povo do Maranhão e Pará, do que se ocupou a Provisão de 17 de outubro de 1653, reconhecendo que daquela proibição do de poderem cativar índios "não resultara utilidade alguma, antes grande perturbação nos moradores, prometendo maiores danos para o futuro, por ser dificultosíssimo, e quase impossível dar liberdade a todos sem distinção".

E nela se determinou "que os oficiais das Câmaras do Maranhão e Pará examinassem em presença do Desembargador sindicante, que então andava naquelas Capitanias, e na sua falta perante os Ouvidores delas, quais aos índios cativados até aquela época, o tinham sido legìtimamente e com boa consciência, e quais não; e que, segundo as deliberações aprovadas e julgadas pelo dito Desembargador, ou Ouvidores, assim fôssem os índios declarados livres, ou escravos".

No exame, a que se procedesse, haver-se-iam como de cativeiro, precedendo guerra, os casos de impedir o gentio, quer livre e independente, quer vassalo e submetido, a pregação do Evangelho; de recusar-se a defender a vida e fazenda dos vassalos d'El-rei em qualquer parte; de lançar-se, com os inimigos da Coroa, dando ajuda contra os vassalos dela; e de exercitar latrocínio por mar ou por terra, infestando os caminhos, salteando ou impedindo o comércio e trato dos homens. 
Seriam também justos os cativeiros dos índios vassalos que faltassem às obrigações que haviam aceitado nos princípios da conquista, negando os tributos e não obedecendo quando chamados para o serviço real de paz ou de guerra; que comessem carne humana. Igualmente se reputariam legítimos escravos os índios que estivessem, em poder dos seus inimigos, atados à corda para serem comidos, e pelos vassalos d'El-rei fôssem remidos daquele perigo, com as armas ou outras vias; e os que já eram legítimos escravos de outros índios, de que fôssem tomados em justa guerra, ou havidos por meio de comércio e resgate.

Far-se-iam, para êsse efeito, entradas ao sertão, com religiosos que fôssem à conversão do gentio, e com pessoas escolhidas em cada Capitania, à pluralidade de votos do Capitão-mor, Oficiais da Câmara, Vigário Geral (onde houvesse) e Prelados das religiões.

Oferecendo-se casos de cativeiros licitos durante as entradas, seriam justificados perante os religiosos que nelas fôssem ${ }^{31}$.

Mas a Provisão, que assim dispunha, não durou muito.

Tão despeitado ficou o Padre Antônio Vieira, disse-o João Francisco LisBoa, com ela, que partiu sem demora para a Côrte, depois de haver pregado, em dia de Santo Antônio, o famoso sermão aos peixes.

E obteve a Provisão de 9 de abril de 1653, em que se decretou:

a) que houvesse uma Junta de Missões, espécie de Tribunal consultivo, especial e privativo para esta matéria, como os havia para os negócios da Fazenda, Ultramar e outros;

b) que as aldeias e índios de todo o Estado do Maranhão fôssem governados e estivessem sob a disciplina dos

31. P. Raphaet M: Galanti, $S$. J., Compêndio de História do Brasil, São Paulo, 1902, Tip. a Vapor de Duprat \& C., v. II, p. 432, n. ${ }^{\circ} 370$. 
religiosos da Companhia, e que o Padre Antônio Vieira, como superior de todos, determinasse as missões, ordenasse as entradas no sertão e dispusesse os índios convertidos à fé pelos lugares que julgasse mais convenientes;

c) que os governadores dessem tôda a ajuda a favor aos missionários, com que se lhes facilitasse o necessário para a conversão dos gentios, que as tiranias traziam afugentados, e remontados da Igreja;

d) que os missionários tivessem voto nos exames dos escravos, em ordem a atalhar as violências que se faziam aos índios ou outros, sendo o cabo da escolta da entrada pessoa aprovada pelos mesmos missionários, e o tempo e lugares das missões marcados pelo padre superior;

e) que os índios cristãos e aldeados não pudessem ser constrangidos a servir mais que sòmente seis meses cada ano, e êstes mesmos alternados de dois em dois, pagando-se -lhes duas varas de pano de algodão por mês;

f) que não se pusessem capitães nas aldeias, antes que nelas fôssem os índios governados pelos principais das suas nações juntamente com seus párocos.

20. Essas novas resoluções, no dizer de Perdigão Malheiro, postas em execução pelo Padre Antônio Vieira e André Vidal de Negreiros, Governador do Estado do Maranhão, "indo de encontro aos intentos e hábitos desumanos no cativar os indios, produziram mais tarde os seus naturais ef eitos na luta que de novo se travou entre os mesmos e os jesuitas. Por enquanto prosseguiam êstes, sob a direção de Vieira, nas suas missões; chegando a fazerem diversos da Companhia, e entre êles o próprio VieIra, várias entradas no sertão para a descida e conversão do gentio (em uma destas fizeram 240 prisioneiros, os quais, conforme a lei de Sua Majestade, a título de haverem impedido a pregação do Evangelho, foram julgados por escravos e entregues aos 
soldados) como se lê em Carta de Vieira de 11 de janeiro de 1660 "32.

Cresceu a exasperação contra os jesuitas a tal ponto, que, em 1662, vários foram presos e, com o Padre AnTônio Vieira, remetidos para Lisboa, detidos outros em Belém do Pará.

Não tardou que Provisão de 12 de setembro de 1663 viesse a proibir aos jesuitas qualquer jurisdição temporal sôbre os índios, determinando que, no espiritual, fôssem todos postos em pé de igualdade, "por ser justo que todos sejam obreiros da vinha do Senhor".

- Poderiam os índios todavia ser removidos, quando se tornasse conveniente, "sem que pudessem as religiões ter aldeias próprias de índios forros de administração; e, no temporal, poderiam ser governados por algum dos seus principais, decidindo sôbre suas queixas e causas os governadores e autoridades civis, como para os demais vassalos se achava determinado".

El-rei D. Pedro II, pela lei de $1 .^{\circ}$ de abril de 1680 , e José Bonifácio DE ANDRADE E Silva observou, cortou pela raiz os quatro casos de que abusavam os colonos para continuar com a escravidão dos índios, que a lei de 1665 permitia; e parecia que "ficava esta pobre gente para sempre isenta de ser escrava; mas não sucedeu assim, porque nestes últimos tempos, em um só século tão alumiado como o nosso, na Côrte do Brasil foram os botucudos e purús do Norte, e os bugres de Graraguava convertidos, outra vez, de prisioneiros de guerra, em miseros escravos" $"$.

Não tinham os indios dessarte proteção adequada, a despeito dos atos promulgados em prol de sua libertação. Nem podiam clamar contra os seus opressores.

32. Agostinho Marques Perdigão Malheiro, A Escravidão no Brasil, Ensaio Histórico-Jurídico-Social, São Paulo, 1944, Edições Cultura, v. II, p. 432 , n. ${ }^{\circ} 370$.

33. AFrânio Peixoto e Constâncio Alves, José Bonifácio ( $O$ velho e o môço). Paris e Lisboa, 1920, Livrarias Aillaud e Bertrand, p. 107. 
21. Não foi a Corôa, em verdade se diga, insensível ao sofrimento dos escravos pela crueldade disciplinar de seus senhores, destituídos, de ordinário, para com êles, de sentimentos humanos.

Carta Régia de 20 de março de 1688, determinou que os senhores não castigassem cruelmente seus escravos, sob pena de os que assim procedessem serem obrigados a vendê-los a quem lhes desse bom tratamento. Era a penalidade de difícil aplicação. Eis porque, três dias depois, outra Carta Régia se expediu, autorizando os governadores a castigar, a seu arbitrio, os que se houvessem com crueldade. Sendo todavia grave o excesso do castigo, fariam, contra êles, proceder sumàriamente pela Justiça; mas de modo a que tais procedimentos não chegassem à notícia dos escravos, de molde a que disso não se prevalecessem para se insubordinarem. Teriam os procedimentos, em tais condições, que correr em segrêdo de Justiça.

Recomendava aquêle documento que os Bispos vigiassem pelos escravos, denunciando aos governadores os excessos que se praticassem, por contrários não sòmente às cartas régias e também à caridade cristã.

É de imaginar que tais dispositivos tivessem suscitado distúrbios e reclamações, porque aquelas duas cartas régias foram, logo depois, revogadas pela de 23 de fevereiro de 1689. Vigorariam, de então em diante, as leis gerais, fazendo-se entender isso mesmo aos escravos, por algumi ato positivo que os desenganasse das ilusões em que por ventura estivessem.

De resto, e merece registro, Carta Régia de 17 de marco de 1663, já havia estabelecido que os governadores providenciassem para que os senhores não deixassem morrer os escravos sem os últimos sacramentos, como tantas vêzes acontece, ou por desumanidade dos senhores, ou por avareza dos parócos, que exigiam, para os ministrar, conhecenças exorbitantes.

Determinou, de resto, Carta Régia de 20 de outubro de 1690, que o Governador do Estado do Maranhão pro- 
pusesse o orçamento, assim da fábrica dum hospital para os índios, como do seu custeio anual, a fim de se evitar que perecessem quase todos os que costumavam vir nos descimentos, como ordinàriamente acontecia.

É de crer que tal providência não chegou a realizar-se, tanto mais quanto Carta Régia de 10 de janeiro de 1687; à Câmara de Belém, que representara quanto à miséria do Estado, por causa da morte dos escravos e índios pela parte das bexigas, pedindo à administração das aldeias que os moradores descessem do sertão, indeferiu esta pretensão. Indeferiu-a sob o fundamento de que as leis então em vigor eram as melhores e sem elas não se conseguiriam os fins das missões, em razão do rigor com que os moradores os tratavam. Era essa, ademais, a causa de se haver consumido a maior parte das povoações de que se compunham os sertões circunvizinhos.

Nessa mesma tecla bateu Carta Régia de 20 de novembro de 1699 ao Governador do Maranhão, que havia representado que a maior parte dos missionários, em proveito temporal, traziam os índios extenuados de excessivos trabalhos, faltando, aliás desumanamente, e dá-los aos moradores, que tanta precisão tinham dêles, em razão da mortandade causada pelas bexigas. Determinou-lhe El-rei que admoestasse os missionários, com moderação; e que os moradores fôssem supridos de índios, por meio de resgates feitos de acôrdo com a Junta das Missões.

Exercia esta, em tais têrmos, papel condizente com o dum mercado de escravos.

\section{$\S 40^{\circ}$}

22. Assaz se havia diminuído, por efeito de escravização, a população gentia da costa brasileira.

Fatôres inúmeros para isso contribuiram.

Era o índio incompatível com o estado de civilização. 
Com efeito, observou José Bonifácio de Andrade e Silva, "o homem no estado selvático, e mormente o índio bravo do Brasil, devia ser preguiçoso; porque tem poucas, ou nenhumas necessidades; porque sendo vagabundo, na sua mão está arranchar-se sucessivamente em terrenos abundantes de caça ou de pesca, ou mesmo de frutos silvestres, e espontâneos, porque vivendo todo o dia exposto ao tempo não precisa de casas, e vestido cômodos, nem dos melindres do nosso luxo; porque finalmente não tem idéia da propriedade, nem desejo de distinção, e vaidades sociais, que põem em atividade o homem civilizado. Demais, uma razão sem exercício, e pela maior parte já corrompida por costumes e usos brutais, além de apático, o deve fazer também estúpỉdo".

Não obstante, acrescentou que "a facilidade de os domesticar era tão conhecida dos missionários, que o Padre Nóbrega, segundo refere o Vieira, dizia por experiência própria, que com música e harmonia de vozes, se atrevia a trazer a si todos os gentios da América. Os jesuitas conheceram que, com presentes, promessas e razões claras e sãs, expedidas por homens práticos na sua língua, paciência e bom modo, podiam fazer dos índios bárbaros o que dêles quizessem".

Foi o que se tornou impossivel e ensejou o estado permanente de guerra, em que viveram colonos e portuguêses: êstes preocupados por escravizá-los; aquêles, por se manterem, no seu estado de barbárie, com o de liberdade, que: Deus lhe dera.

O procedimento escravizador, do norte ao sul da costa brasileira, seccionou o estado de tranqüilidade, em que poderiam conviver, lado a lado, portuguêses e colonos.

Mas o estado de luta, que o de escravidão do gentio provocaria, redundou em prejuízo constante para o gentio. Vencido e escravizado, pela sua inferioridade, em todos os aspectos, os que não conseguiram embrenhar-se no sertão, se escravizaram. Escravo, não logrou o gentio, ordinàriamente, sobrevivência ao pêso do trabalho, a que 
não estava afeito, e das angústias dos sofrimentos físicos, que não foi possível suportar. Ademais, não curado das enfermidades, que lhe corromperam o organismo desafeito ao novo modo de viver, o gentio, há pouco e pouco, se foi convertendo em pó.

Fêz horror ao Padre Antônio Vieira "refletir na rápida despovoação dêstes miseráveis, depois que chegou ao Brasil: basta notar, como refere o PAdRe VieIRA, que em 1605, em que se conquistou o Maranhão, havia desde a cidade até o Gurupá mais de 500 aldeias de índios, tôdas numerosas, e algumas delas tanto, que deitavam quatro a cinco mil arcos, mas quando o dito ViEIRA chegou, em 1652, ao Maranhão, já tudo estava consumido e reduzido a mui poucas aldeias, de tôdas as quais não pôde ANDRÉ VIDAL DE Negreiros ajuntar 800 índios de armas. Calculou o Padre VIEIra que, em 30 anos, pelas guerras, cativeiros e moléstias, que lhes trouxeram os portuguêses, eram mortos mais de dois milhões de indios" ${ }^{4}$.

$\mathrm{E}$ isto, é de registrar, sòmente no Estado do Maranhão. Não teria sido diferente, e não foi, no Estado do Brasil.

23. No propósito de lhes melhorar a sorte, quando, em 1652, se restaurou a Relação da Bahia, em seu regimento se recomendou ao Governador proteção aos índios, de modo a não consentir que "fôssem maltratados, fazendo punir com rigor quem os molestasse e maltratasse; assim como a que desse ordem a que pudessem viver junto das povoações dos portuguêses, de modo que os do sertão folgassem de vir para as ditas povoações, observando-se a lei de $\mathrm{D}$. SEBaSTIÃo e provisões posteriormente promulgadas".

No mesmo sentido se manifestou o Regimento da Relação do Rio de Janeiro, criada por lei de 16 de fevereiro de 1751.

34. José Bonifácio de ANdrade e Silva, Apontamentos para a Civilização dos fndios Bravos do Império do Brasil, em AlBERTo SouzA, Os Andradas, São Paulo, 1922, Tipografia Piratininga, v. III, p. 472 e 475 . 
24. Cuidou a Coroa de valorizar o índio, elevando-o. no conceito público. Foi por Ałvará de 4 de abril de 1755. Considerando El-rei quanto convinha a seus reais domínios da América que se povoassem e que, para êsse fim, poderia: concorrer a comunidade dos índios, por meio de casamentos, declarou que seus vassalos do Reino e da América, que casassem com as índias dêstes, não ficariam com infâmia alguma, antes se fariam dignos de sua real atenção. Nas terras, em que se estabelecessem seriam preferidos para aquêles lugares e ocupações que coubessem na graduação de suas pessoas. Seus filhos e descendentes reputar-se-iam hábeis e capazes de qualquer emprêgo, honra ou dignidade, sem que necessitassem de dispensa alguma, em razão daquelas alianças, nas quais se compreenderiam as já anteriormente feitas.

Por igual, as portuguêsas, que casassem com indios, e seus filhos e descendentes, gozariam dos mesmos direitos: e vantagens.

Quando os advindos de tais uniões conjugais tivessem algum requerimento na dependência de Sua Majestade, far-se-lhe-ia saber dessa particularidade para serem mais particularmente atendidos.

Ademais terminantemente se proibiu que fôsse tratado o epíteto de "caboclos", ou idêntico que pudesse ser" injurioso.

Tiveram os indios e indias, consorciados com portuguêses, e seus descendentes, sua carta de cidadania ${ }^{35}$.

25. De maior amplitude, alcance e reflexos, se mostrou a lei de 6 de junho de 1755 .

Considerou por ela El-rei que, verificando as causas pelas quais não se havia até então multiplicado e civilizado os índios do Estado do Maranhão, desterrando-se dela a barbaridade e o gentilismo e propagando-se a doutrina:

35. Waldemar Ferreira, $O$ Direito Público Colonial do Estado do. Brasil sob o signo Pombalino, Rio de Janeiro, 1960, Editôra Nacional de Direito Ltda., p. 26 a 29. 
cristã; e que os índios, descidos de suas aldeias, em vez de prosperarem e propagar-se, se foram extinguindo, de modo a ser assaz reduzido o número de suas povoações e dos moradores delas, vivendo êsses poucos dispersos pelos matos, declarou-os livres e isentos de tôda a escravidão, de molde a poderem dispôr de suas pessoas e bens, como melhor lhes parecesse, sem outra sujeição temporal que não fôsse às suas leis, para à sombra delas viverem na paz e união cristã e na sociedade civil em que, mediante a divina graça, procurava manter os povos que Deus lhe confiara.

Nesta se incorporariam os índios, sem distinção ou restrição alguma, para gozarem de tôdas as honras, privilégios e liberdades, de que seus vassalos gozavam então, conforme as suas graduações e cabedais, inclusive os que estivessem possuídos como escravos.

Excetuou da magnanimidade majestática, no entanto, aquela lei sòmente os oriundos de pretas escravas, os quais seriam conservados no domínio de seus senhores, enquanto não desse providência sôbre aquela matéria.

26. Continuaram escravos todavia os índios do Estado do Brasil.

Por alvará de 8 de maio de 1758, de conformidade com - Breve Immensa Pastorum, do Papa Benedito xiv, que reprovara os abusos contra a liberdade dos índios do Brasil, EI-rei D. JosÉ declarou livres êstes índios, sem restrição alguma, para que fôssem julgados, em tudo e por tudo, como os das Capitanias do Grão Pará e do Maranhão.

Não obstante, regimento de 3 de maio de 1757 , que se celebrizou com o nome de - Diretório, reconheceu a impossibilidade de se realizarem imediatamente as intenções reais atinentes à liberdade dos indios. Deu-lhes uma como liberdade tutelada. Pô-los debaixo do govêrno dos seus respectivos maiorais, em razão da deplorável ignorância em que tinham sido criados, até se mostrarem capazes de por si mesmo se dirigirem e aos seus bens. Teria cada 
aldeamento seu diretor, que fôsse homem de inteireza, zelo, prudência, bons costumes e conhecedor da língua indígena. Investiram-se os juizes de autoridade temporal, nas vilas criadas, e os maiorais nas aldeias independentes. Outras e inúmeras providências foram ditadas, no propósito de proteger os índios liberados da escravidão, a fim de que não viessem, por ludibrio, a cair sob o regime desta ${ }^{36}$.

Êsse regimento, homologado por Alvará de 17 de agôsto de 1758 , em razão de proposta de D. Francisco de Souza Coutinho, Governador da Capitania do Grão Pará, veio a ser derrogado por Carta Régia de 12 de maio de 1798, reinante D. MARIA I.

Cairam os índios então sob o regime do direito comum.

27. E os negros?

Continuariam êsses, que eram em maior número que os indios, durante quase um século, em regime de escravidão.

Mas essa é outra história.

36. Roberto Southey, História do Brasil, Trad. de Oliveira e Castro, Cidade do Salvador (Bahia), Livraria Progresso Editôra, v. vr, p. 60 . 